\title{
DROSOPHILA SUZUKII (MATSUMURA, 1931) (DIPTERA: DROSOPHILIDAE), A NEW INVASIVE PEST IN SERBIA
}

\author{
IVO TOŠEVSKI ${ }^{1}$, SLOBODAN MILENKOVIĆ ${ }^{2}$, OLIVER KRSTIĆ', \\ ANDREA KOSOVAC ${ }^{1}$, MILJANA JAKOVLJEVIĆ', MILANA MITROVIĆ, \\ TATJANA CVRKOVIĆ ${ }^{1}$ JELENA JOVIĆ ${ }^{1}$
}

${ }^{1}$ Institute for Plant Protection and Environment, Department of Plant Pests, Zemun

${ }^{2}$ Megatrend University, Faculty of Biofarming, Bačka Topola, e-mail:toseuski_ivo@yahoo.com

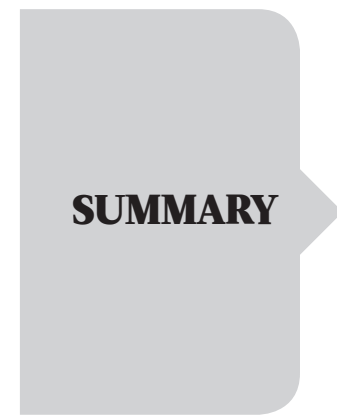

During October and November 2014, a survey was conducted in order to establish the presence of the invasive pest Drosophila suzukii (Matsumura, 1931) on the territory of Serbia. Survey revealed the presence of this fly in four districts (Rasinski, Mačvanski, Raški and Pčinjski), in sampled raspberry and blackberry ripe fruits, as well as in common fig and grape. Collected fruits were used for the rearing of Drosophilid larvae to adults, which were subsequently subjected to morphological and molecular characterization. The presence of D. suzukii was confirmed in all surveyed districts, as well as in Zemun (City of Belgrade). This is the first report of the highly invasive fruit pest D. suzukii on the territory of Serbia.

Key words: Drosophila suzukii, new invasive pest, Serbia

\section{INTRODUCTION}

Spotted wing drosophila (SWD) or Drosophila suzukii (Matsumura, 1931) is a highly polyphagous invasive species originating from South East Asia. Expanding distribution in past several years undoubtedly confirmed a high potential of this species to disperse. The first record out of the native range is related with Hawaii islands where $D$. suzukii colonized both islands during 1980 (Hauser, 2011). For the first time, D. suzukii was recorded in North America at the beginning of autumn 2008 in California, with rapid spread during 2009 along the west coast of and deep penetration inside the mainland, while in 2010, D. suzukii adults were recorded along the east coast of United States, as well as in Canada (Hauser, 2011).

Parallel to the events in North America, D. suzukii was reported in 2008, first in Spain and in the late autumn in Italy and France. Over the following years, this species was reported in several countries in Europe, confirming once again an extraordinary fast ability of long distance dispersal (Calabria et al., 2012; Mortelmans et al., 2012; Baufeld et al., 2010; Burrack et al., 2012). Subsequent records of D. suzukii are related with Slovenia and Croatia (Milek et al., 2011), Bosnia and Herzegovina (Ostojić et al., 2014) and Montenegro in 2014 (Radonjić, 2014, personal communication). In the short period of time, D. suzukii became one of the worst pests, particularly on berry and cherry fruits, while the impact on vineyards is also of concern especially in the temperate regions (Saguez, 2013).

A total of three Drosophila species are ascribed within the D. suzukii species subgroup of Oriental distribution that phylogenetically belongs to the Drosophila melanogaster species group: Drosophila suzukii (Matsumura, 1931), D. pulchrella Tan, 1949 and D. subpulchrella Takamori and Watabe, 2006. All three species are characterized by the two black spots on male wings while female possesses a pronounced serrated ovipositor (Takamori et al., 2006). Thus far, D. suzukii is the only species of the D. melanogaster group in Europe characterized 
by a serrated ovipositor present in females and spotted wings present in males.

During October 2014, we received samples of drosophoilid larvae from surroundings of the village Vrdila (near Kraljevo, Raški district), with general concern of raspberry producers that these larvae may cause particular losses in raspberry and blackberry plantations. Molecular analysis of the larvae confirmed that larvae belong to the Drosophila suzukii. Having in mind that the presence of SWD was not reported for Serbia, a comprehensive survey was performed during October and November to locate distribution of the new pest in the main regions where cultivation of raspberry and blackberry is dominant agricultural activity. Thus, results in this paper represent preliminary knowledge about the presence of spotted wing drosophila Drosophila suzukii in Serbia with its confirmed and predicted distribution.

\section{MATERIAL AND METHODS}

\section{Insects sampling}

The survey was conducted from the beginning of October to the end of November 2014. We have primarily collected ripe fruits of raspberry, blackberries and grapevine from commercial plantations or individual plants from Central Serbia (village Latkovac, Rasinski district), north-west Serbia (Zavlaka, Mačanski district), south-west Serbia (village Vrdila, Raški district), while individual samples of raspberry and figs fruit (Ficus carica, Moraceae) were collected from south Serbia (Vranje, Pčinjski district) and Zemun (Territory of Belgrade) (Table 1). Taking into account that the period of sampling was conducted in late autumn and that outdoor temperature was too low to identify SWD presence, we have concentrated our sampling efforts on collecting rape fruits that may contain D. suzukii larvae. Approximately 100 of ripe fruits per sample were collected and set inside well ventilated plastic box $(17 \times 11 \times 6 \mathrm{~cm})$. Subsequently the fruits were transferred into laboratory conditions for rearing at $24^{\circ} \mathrm{C} \pm 1$ in day/ night regime 16/8 hours. The emerged adults were kept inside a rearing box for the following 3 days, when collected by a mouth aspirator, and stored in $96 \%$ ethanol at $5-7^{\circ} \mathrm{C}$ until morphological and molecular analysis.

\section{Morphological and molecular identification of Drosophila suzukii}

Morphological identifications were taken under a stereomicroscope Leica MS5, and confirmed by a molecular analysis by sequencing the barcoding region of the cytochrome oxidase subunit 1 gene (COI) of the emerged adults from the particular sampling locality (Table 1 ).

Individual adults were punctured between the 2nd and 3rd thoracic sternites, and total DNA was extracted using the QIAGEN Dneasy ${ }^{\circledR}$ Blood \& Tissue Kit (Qiagen, Hilden, Germany) according to the manufacturer's instructions. The barcoding region of the mitochondrial cytochrome oxidase subunit I gene (mtCOI) was amplified using the primers (Folmer et al., 1994) LCO1490 (5'-GGTCAACAAATCATAAAGATATTGG-3') and HCO2198 (5'-TAAACTTCAGGCTGACCAAAAAATCA-3').

Polymerase chain reaction (PCR) was performed in a $20 \mu \mathrm{L}$ final volume containing Kapa Biosystems High Yield Reaction Buffer A with 1.5 $\mathrm{mM} \mathrm{MgCl}(1 \times)$, an additional $2.25 \mathrm{mM}$ of $\mathrm{MgCl}_{2}$, $0.6 \mathrm{mM}$ of each dNTP, $0.5 \mu \mathrm{m}$ of each primer, $1 \mathrm{U}$ of KAPATaq DNA polymerase (Kapa Biosystems, Inc., Woburn, MA, USA) and $1 \mu \mathrm{L}$ of DNA extract. PCR cycles were carried out in a Mastercycler ep gradient S (Eppendorf, Hamburg, Germany) applying the following thermal steps for amplification of the COI barcoding region: $95^{\circ} \mathrm{C}$ for 5 min (initial denaturation), 35 cycles at $94^{\circ} \mathrm{C}$ for $1 \mathrm{~min}, 54^{\circ} \mathrm{C}$ for $1 \mathrm{~min}$ (annealing), $72{ }^{\circ} \mathrm{C}$ for $1.5 \mathrm{~min}$ and a final extension at $72^{\circ} \mathrm{C}$ for $7 \mathrm{~min}$. The amplified products of the $\mathrm{mt}-$ COI gene were sequenced with the forward primer only. The sequencing was performed on an ABI Prism 3700 automated sequencer using the commercial services of Macrogen Inc. (Seoul, South Korea). Sequence of COI gene was deposited in the GenBank database under accession number KP233882).

\section{RESULTS}

According to our preliminary study, the presence of the D. suzukii was confirmed in all sampled material from five districts in Serbia, i.e. from Rasinski, Raški, Mačvanski, Pčinjski and City of Belgrade (Fig 1.). Sequence analysis of the selected specimens from all districts where D. suzukii was recorded, confirmed $100 \%$ identity of Serbian D. suzukii with COI gene sequence HM636439 from Spain (Calabria et al., 2012). 


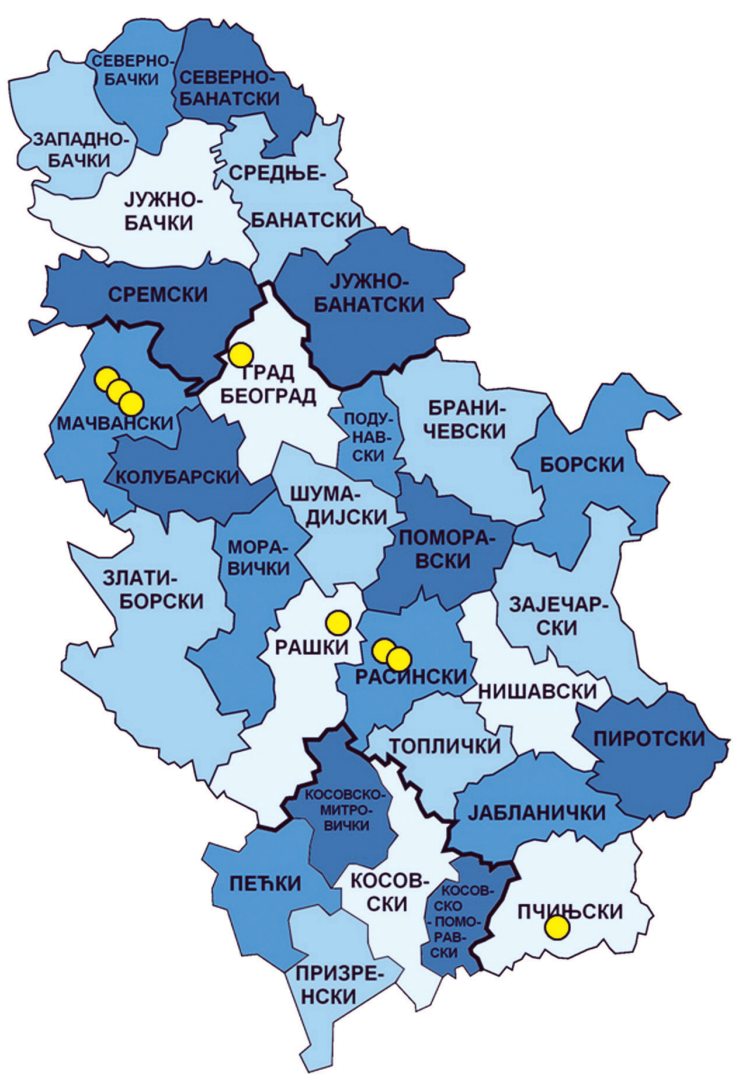

Figure 1. Confirmed distribution of Drosophila suzukii on the territory of Serbia in autumn 2014. Slika 1. Potvrđeno rasprostranjenje Drosophila suzukii na teritoriji Srbije u jesen 2014. godine.

In morphological sense, specimens of $D$. suzukii do not differ from the specimens of this species recorded in other parts of Europe. Adults are approximately $2-3 \mathrm{~mm}$ in length with females slightly larger than males. The females of $D$. suzukii are habitually similar to D. melanogaster but comparing to latter, they possess a distinctly serrated ovipositor (Fig. 2 - A, B) which allows them to break the skin of healthy fruits. The males possessed pronounced black sub-apical spot on the forewing (Fig. 2 - C). These two morphological characters clearly distinguish D. suzuki from other Drosophila species distributed in Serbia.

The eggs of D. suzukii are white and glossy, on average $0.6 \times 0.2 \mathrm{~mm}$ wide with two subapical dorsal appendages. There are three larval instars that range in size $0.7-9 \mathrm{~mm}$ white to cream in colour with visible internal organs and cephalopharyngeal skeleton (Fig. 2 - D). The pupae of D. suzukii are brown in color and about $3 \mathrm{~mm}$ long and by 1 $\mathrm{mm}$ wide with anterior spiracles on both sides of the head (Fig. 2 - E).

In our collected material, D. suzukii was the

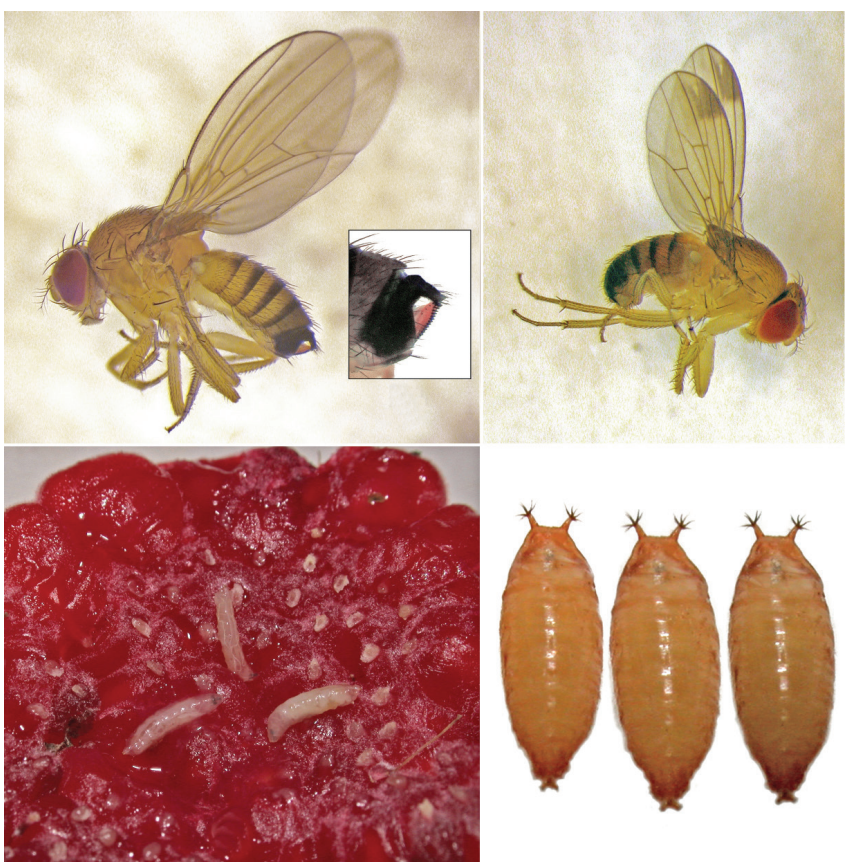

Figure 2. Drosophila suzukii, collected from the village Latkovac, Aleksandrovac region (Rasinski district): A - female; B - serrate ovipositor (detail); C - male with typical black spots subapically; D L3 larvae insĐide raspberry fruit; E - pupae.

Slika 2. Drosophila suzukii, sakupljena u selu Latkovac, okolina Aleksandrovca (Rasinski okrug): A - ženka, B - nazubljena legalica; C - mužjak sa tipičnim crnim tačkama na krilima; D - larve L3 stadijuma u plodu maline; $\mathrm{E}$ - lutke.

most abundant in Mačvanski district (Zavlaka) where 87 adults emerged from 100 raspberry fruits and in Raški district (Vrdila, Kraljevo) with 65 adults from blackberry sample (Table 1 ). Taken together, $D$. suzukii was a dominant species in our sampled material from all surveyed districts, while presence of other Drosophila species (D. melanogaster and D. phalerata), especially in raspberry and blackberry fruit samples was negligible (Table 1). In addition, we frequently recorded presence of $D$. suzukii in common fig fruits, where this species co-occurred with D. simulans, D. melanogaster, D. immigrans, D. phalerata and D. repleta (Table 1).

\section{DISCUSSION}

The preliminary distribution of the drosophilid species sampled in the Serbian districts is given in Table 1. It is worth noting that sampling period for D. suzukii was not optimal for collection of more precise data in regard to its frequency in the attacked fruit. Consequently, obtained results led to conclusion that this new pest is widely distributed in Ser- 
Table 1. Abundance of Drosophila species reared from the collected fruit samples on the territory of Serbia during autumn 2014.

Tabela 1. Prisutnost vrsta Drosophila odgajenih na uzorcima voća na teritoriji Srbije u jesen 2014. godine.

\begin{tabular}{|c|c|c|c|c|c|}
\hline \multirow{2}{*}{$\begin{array}{l}\text { Locality } \\
\text { (district) }\end{array}$} & \multirow{2}{*}{ GPS coordinate } & \multirow{2}{*}{$\begin{array}{c}\text { Total } \\
\text { number of } \\
\text { samples }\end{array}$} & \multirow{2}{*}{ host fruit } & \multicolumn{2}{|c|}{ Emergence } \\
\hline & & & & total number & $\begin{array}{c}\text { Drosophila species } \\
\text { (frequence) }\end{array}$ \\
\hline \multirow{5}{*}{$\begin{array}{l}\text { Latkovac } \\
\text { (Rasinski) }\end{array}$} & \multirow{5}{*}{ N43 30.127 E20 58.737, 748m } & \multirow{5}{*}{6} & raspberry & 36 & $\begin{array}{l}\text { D. suzukii }(31) \\
\text { D. melanogaster }(2) \\
\text { D. phalerata }(3)\end{array}$ \\
\hline & & & raspberry & 28 & $\begin{array}{l}\text { D. suzukii }(25) \\
\text { D. melanogaster }(1) \\
\text { D. phalerata }(2)\end{array}$ \\
\hline & & & blackberry & 17 & $\begin{array}{l}\text { D. suzukii }(15) \\
\text { D. melanogaster }(1) \\
\text { D. phalerata }(1)\end{array}$ \\
\hline & & & blackberry & 22 & $\begin{array}{l}\text { D. suzukii (18) } \\
\text { D. phalerata (4) }\end{array}$ \\
\hline & & & grape & 4 & $\begin{array}{c}\text { D. suzukii }(2) \\
\text { D. melanogaster }(2)\end{array}$ \\
\hline $\begin{array}{l}\text { Aleksandrovac } \\
\text { (Rasinski) }\end{array}$ & N43 27.595 E21 02.280, 378m & 1 & common fig & 68 & $\begin{array}{l}\text { D. suzukii }(22) \\
\text { D. simulans }(29) \\
\text { D. phalerata }(1) \\
\text { D. repleta }(1)\end{array}$ \\
\hline $\begin{array}{l}\text { Latkovac } \\
\text { (Rasinski) }\end{array}$ & N43 30.127 E20 58.737, 748m & 8 & blackberry & $\begin{array}{c}16 \\
14 \\
21 \\
12 \\
25 \\
15 \\
10 \\
8 \\
\end{array}$ & $\begin{array}{l}\text { D. suzukii }(15) \\
\text { D. melanogaster }(1) \\
\text { D. suzukii }(14) \\
\text { D. suzukii }(21) \\
\text { D. suzukii }(12) \\
\text { D. suzukii }(25) \\
\text { D. suzukii }(15) \\
\text { D. suzukii }(10) \\
\text { D. suzukii }(8) \\
\end{array}$ \\
\hline $\begin{array}{c}\text { Zavlaka } \\
\text { (Mačvanski) }\end{array}$ & N44 28.474 E19 28.994, 239M & 3 & raspberry & $\begin{array}{l}25 \\
87 \\
42\end{array}$ & $\begin{array}{l}\text { D. suzukii (25) } \\
\text { D. suzukii (87) } \\
\text { D. suzukii (42) }\end{array}$ \\
\hline $\begin{array}{c}\text { Maovi } \\
\text { (Mačvanski) }\end{array}$ & N44 41.882 E19 37.034, 103м & 1 & common fig & 2 & D. suzukii (2) \\
\hline $\begin{array}{c}\text { Varna } \\
\text { (Mačvanski) }\end{array}$ & N44 39.555 E19 39.275, 140M & 1 & common fig & 3 & D. suzukii (3) \\
\hline $\begin{array}{l}\text { Kraljevo } \\
\text { (Raški) }\end{array}$ & N43 42.520 E20 33.360, 256m & 2 & $\begin{array}{l}\text { blackberry } \\
\text { blackberry }\end{array}$ & $\begin{array}{l}65 \\
2 \\
\end{array}$ & $\begin{array}{l}\text { D. suzukii (61) } \\
\text { D. melanogaster (4) } \\
\text { D. suzukii (2) }\end{array}$ \\
\hline $\begin{array}{c}\text { Zemun } \\
\text { (City of Beograd) }\end{array}$ & $\begin{array}{c}\text { N44 51.320 E20 } 22.630, \\
92 \mathrm{M}\end{array}$ & 2 & common fig & 32 & $\begin{array}{c}\text { D. suzukii (6) } \\
\text { D. suzukii (8) } \\
\text { D. immigrans }(24)\end{array}$ \\
\hline$\underset{\text { (Pčinjski) }}{\text { Vranje }}$ & N42 33.150 E21 54.030, 467m & 1 & common fig & 75 & $\begin{array}{l}\text { D. suzukii (18) } \\
\text { D. melanogaster (22) } \\
\text { D. simulans (35) }\end{array}$ \\
\hline
\end{tabular}

bia, with populations established at altitude from $70-800 \mathrm{~m}$. Therefore, we expect that D. suzukii is already present in several other important districts in Serbia with predominant agricultural production of raspberry and blackberry. Recorded widespread of this invasive organism in Serbia is in concordance with the fast spread across Western Europe and it is of objective concern for further production of fruits in regions where D. suzukii is established. Taking into account the experience of other European $\mathrm{CO}^{-}$ untries (Cini et al., 2012, EPPO), the presence of $D$. suzukii consequently leads to serious changes in the strategy of cultivation of the most targeted fruit cultures, in the first place cherry, raspberry and blac- 
kberry. The territory of Serbia is especially suitable for bio-ecological demands of D. suzukii because of the temperate climate. In addition, cultivation of raspberry and blackberry are main activities in hilly regions in central and western part of Serbia. Therefore, we expect that the new invasive Drosophila species will substantially change the production strategy of fruits in further period.

\section{ACKNOWLEDGEMENTS}

Results of this research were funded by Plant Protection Directorate, Ministry of Agriculture, Forestry and Water Management of Republic of Serbia, contract number 321-01-134/2014-11 and by research grant from the Ministry of Education, Science and Technological Development of the Republic of Serbia, No. III43001 and TR31043.

\section{REFERENCES}

Baufeld, P., Schrader, G., Unger, J. G. (2010): Die Kirschessigfliege: Drosophila suzukii-Ein neues Risiko für den Obst-und Weinbau. Journal für Kulturpflanzen, 62(5): 183-186.

Burrack, H. J., Smith, J. P., Pfeiffer, D. G., Koeher, G., Laforest, J. (2012): Using volunteer-based networks to track Drosophila suzukii (Diptera: Drosophilidae) an invasive pest of fruit crops. Journal of Integrated Pest Management, 3(4), B1-B5.

Bulletin OEPP/EPPO Bulletin (2013) 43 (3), 417-424. http://www.eppo.int/QUARANTINE/Alert_List/insects/ Drosophila_suzukii_factsheet_12-2010.pdf

Calabria, G., Máca, J., Bächli, G., Serra, L., Pascual, M. (2012): First records of the potential pest species Drosophila suzukii (Diptera: Drosophilidae) in Europe. Journal of Applied entomology, 136(1-2): 139-147.

Cini, A., Ioriatti, C., Anfora, G. (2012): A review of the invasion of Drosophila suzukii in Europe and a draft research agenda for integrated pest management. Bulletin of insectology, 65(1): 149-160.

Folmer, O., Black, M., Hoeh, W., Lutz, R., Vrijenhoek, R. (1994): DNA primers for amplification of mitochondrial cytochrome c oxidase subunit I from diverse metazoan invertebrates. Molecular marine biology and biotechnology, 3: 294-299.

Hauser, M. (2011): A historic account of the invasion of Drosophila suzukii (Matsumura)(Diptera: Drosophilidae) in the continental United States, with remarks on their identification. Pest management science, 67(11): 1352-1357.

Milek, T. M., Seljak, G., Šimala, M., Bjeliš, M. (2011): First record of Drosophila suzukii (Matsumara, 1931)(Diptera: Drosophilidae) in Croatia. Glasilo Biljne Zaštite, 11(5): 377-382.

Mortelmans, J., Casteels, H., Beliën, T. (2012): Drosophila suzukii (Diptera: Drosophilidae): A pest species new to Belgium. Belgian Journal of Zoology, 142(2): 143-146.

Ostojić I., Bulić P., Zovko M., Petrović D., Dogan V. (2014): Ocatana mušica ploda (Drosophila suzukii Matsumura,1931) - Novi član entomofaune u Bosni i Hercegovini. XI Simpozijum o zaštiti bilja u Bosni i Hercegovini, Teslić, 2014.

Saguez, J., Lasnier, J., \& Vincent, C. (2013): First record of Drosophila suzukii in Quebec vineyards. Journal International des Sciences de la Vigne et du Vin, 47(1): 69-72.

Takamori, H., Watabe, H. A., Fuyama, Y., Zhang, Y. P., Aotsuka, T. (2006): Drosophila subpulchrella, a new species of the Drosophila suzukii species subgroup from Japan and China (Diptera: Drosophilidae). Entomological science, 9(1): 121-128. 
$\underline{104}$

\title{
DROSOPHILA SUZUKII (MATSUMURA, 1931) (DIPTERA: DROSOPHILIDAE), NOVA INVAZIVNA VRSTA U SRBIJI
}

\author{
IVO TOŠEVSKI ${ }^{1}$, SLOBODAN MILENKOVIĆ ${ }^{2}$, OLIVER KRSTIĆ1, \\ ANDREA KOSOVAC ${ }^{1}$, MILJANA JAKOVLJEVIĆ ${ }^{,}$, MILANA MITROVIĆ ${ }^{\text {, }}$ \\ TATJANA CVRKOVIĆ' ${ }^{1}$ JELENA JOVIĆ ${ }^{1}$ \\ ${ }^{1}$ Institut za zaštitu bilja i životnu sredinu, Odsek za štetočine bilja, Zemun \\ ${ }^{2}$ Univerzitet Megatrend, Fakultet za Biofarming, Bačka Topola \\ e-mail:toseuski_ivo@yahoo.com
}

REZIME

Tokom oktobra i novembra 2014. godine, sprovedena su istraživanja u cilju utvrđivanja prisustva i rasprostranjenja invazivne štetočine Drosophila suzukii (Matsumura, 1931) na teritoriji Srbije. Prisustvo ove mušice je utvrđeno u okviru četiri okruga (Rasinski, Mačvanski, Raški, Pčinjski), u uzorkovanim plodovima maline, kupine, smokve i grožđa. Iz plodova su odgajene Drozofilidne larve do adulta koji su zatim analizirani morfološki i molekularno. Prisustvo D. suzukii je utvrđeno na svim lokalitetima u okviru četiri okruga, kao i na teritoriji grada Beograda (Zemun). Ovo je prvi nalaz invazivne štetočine voća D. suzukii na teritoriji Srbije.

Ključne reči: Drosophila suzukii, nova vrsta štetočine, Srbija

(Primljeno: 28.11.2014.)

(Prihvaćeno: 18.12.2014.) 